temperature may rise to $104^{\circ} \mathrm{F}$. as a result of belladonna poisoning. In animals, at least, large doses of cocaine will cause a rise of temperature. It is said the best dose for producing this effect is a subcutaneous injection about eight milligrammes per kilogramme of the animal, the dose to be frequently repeated. Strychnine and caffeine, too, will both raise the temperature a little. But by far the most important drug for raising the bodily temperature in $\beta$-tetrahydronaphtbylamine. Some remarkable experiments concerning this drug are given by Stern. ${ }^{18}$ For instance, he took a rabbit weighing 1600 grammes, the temperature of which was $40^{\circ} \mathrm{C}$., and at $10.42 \mathrm{~A}$.M. injected subcutaneously 0.075 grammes of $\beta$-tetrahydronaphthylamine. The temperature was taken every few minutes afterwards with the following results:At 10.55 A.M. the temperature was $40^{\circ}$ C.; at $11.0^{\text {A.M. }}$. it was $40.2^{\circ}$; at $11.8 \mathrm{~A} . \mathrm{M}$. it was $40.9^{\circ}$; at $11.20 \mathrm{~A} \mathrm{M}$. it was $41.4^{\circ}$; at 11.40 A.M. it was $43.0^{\circ}$; at 11.52 A.M. it was $44 \cdot 5^{\circ}$; and at 12.2 P.M. the rabbit died. So that the drug actually raised the temperature $4.5^{\circ} \mathrm{C}$. in an hour. By giving a smaller dose of the drug he was able to obtain a considerable rise of temperature without killing the animal.

Such a remarkable drug appeared to me to be worthy of further investigation, and Dr. J. Fawcett agreeing with me we made some experiments. We employed a 3 per cent. aqueous solution and always gave it subcutaneously. We performed several experiments; the following are the details of one.

The rabbit weighed 2400 grammes. At 1.30 P.M. the rectal temperature before injection was $38.7^{\circ} \mathrm{C}$; ; at 1.35 P.M. 3 c.c. of solution were injected; at 1.55 P.M. the temperature had risen to $393^{\circ}$; at 2.10 P.M. it was $40.5^{\circ}$; at 3.5 P.M. it was $41.5^{\circ}$; at 4 P.M. it reached $41.9^{\circ}$; and from 4.30 to 7 P.M. it gradually fell to $39 \cdot 3^{\circ}$, and the following table (Table XXXIX.) shows the results of all our experiments.

TABLE XXXIX.-Showing the result of injecting a 3 per cent. solution of $\beta$-tetrahydronaphthylamine subcutaneously in five rabbits.

\begin{tabular}{|c|c|c|c|c|c|c|c|c|}
\hline 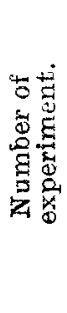 & 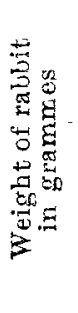 & 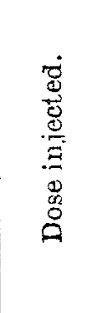 & 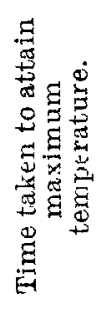 & 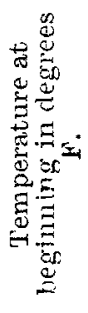 & 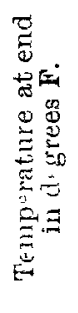 & 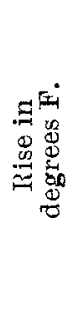 & 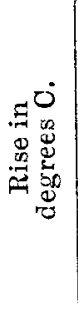 & 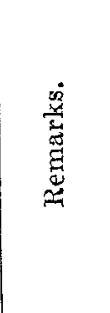 \\
\hline 1. & 2400 & 3 c.c. & 3 hrs. & $101 \cdot 6$ & 1674 & $5 \cdot 8$ & $3 \cdot 2$ & - \\
\hline 2. & 2050 & 3 c.c. & 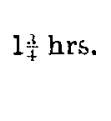 & $102 \cdot 7$ & 1126 & 9.9 & $5 \cdot 5$ & $\begin{array}{l}\text { animal } \\
\text { died ; } \\
\text { greatest } \\
\text { rise. }\end{array}$ \\
\hline 3. & 3570 & 4 c.c & 2 hrs. & 1031 & 1068 & $3 \cdot 7$ & $2 \cdot 1$ & - \\
\hline 4. & 2200 & 3 c.c & $2 \frac{\mathrm{I}}{\mathrm{q}} \mathrm{hrs}$. & 1014 & $104 \cdot 3$ & $2 \cdot 9$ & 16\{ & $\begin{array}{l}\text { Least } \\
\text { rise. }\end{array}$ \\
\hline 5. & 2200 & 3.5 c.c. & $4 \mathrm{hrs.}$ & $101 \%$ & $105 \cdot 0$ & 32 & 22 & - \\
\hline
\end{tabular}

It will be seen that in one animal a rise of $5.5^{\circ} \mathrm{C}$. took place. This died, but all the others recovered, and in one of them there was a rise of as much as $3.2^{\circ} \mathrm{C}$. In all five experiments the pulse and respiration were enormously increased in rapidity, often both were so quick that they were quite uncountable. We never observed any of the variations in the size of the pupil or the vessels of the eye that Stern mentions. As animals which, like rabbits, do not perspire much must lose most of the heat they part with by the lungs, the rise of temperature produced by $\beta$-tetrahydronaphthylamine cannot have been due to a diminution of the loss of heat. Indeed, judging by the rapidity of respiration, this must have been much more rapid than usual, and probably the creature was by increasing its heat loss struggling against the rise of temperature produced by the drug. The animals for an hour or two after the drag was injected were usually rather restless, frequently shifting their position and turning round, but they never ran about or made any prolonged severe muscular movement. This restlessness was always followed by marked loss of muscular power, but nevertheless the temperature continued to rise. The only animal that hac convulsions was the one that died, and they did not appear until shortly before death. These facts seem to me to be strongly in favour of the view that the drug has in some way greatly increased the production of heat, and that this increased production is not due to muscular movement, for the rise is altogether too great and too rapid for it to be caused even in large part by the increased muscular movement due to the greater rapidity of the respiration and pulse. In support of this view I may mention that Stern was also of opinion that the muscular movements were not sufficient to explain the rise of temperature, for in his experiments this sometimes occurred in animals which were quiet without any drug being given to keep them quiet, and also in those which were kept quiet by morphia. Further, the rise of temperature that is seen in animals convulsed with strychnine is never nearly so great as that produced by $\beta$-tetrahydronaphthylamine, although rabbits under the influence of this drug never show muscular contractions comparable to those produced by strychnine. Then, too, some experiments performed by Mosso go to show that even the comparatively slight rise of temperature in strychnine poisoning is not due solely to muscular contractions. I cannot help thinking, therefore, that we have in $\beta$-tetrahydronaphthylamine a drug which stimulates the thermogenetic without exciting the motor function of muscle, and that therefore we see-as we have already seen in the patients afflicted with hemiplegia - that the two functions are distinct.

I have already pointed out in these lectures that damage to the corpus striatum produces a considerable rise of temperature. The rise produced by $\beta$-tetrahydronaphthylamine so resembles in extent and rapidity that caused by these injuries that it is at least likely that the drug acts on the muscles through the central nervous system. Dr. Fawcett and I tried to find out whether this was so, but all the experiments we could devise necessitated fixing the animal down and performing artificial respiration, and, as I have already pointed out, this interferes so much with the animal's temperature that we were unable to obtain any satisfactory answer to the question we attempted to solve.

I have not yet had time to see whether the administration of this drug increases the resistance to any febrile diseases, but it is clear that even if it does it will have to be given very cautiously to man on account of its marked effect on the heart.

The only duty that now remains to me is to thank you for having listened to these lectures, and to express my regret that they should have been so imperfect and fragmentary. This is, for the most part, my fault, but it is also due to the difficulties of the subject. I have not referred to the work of many to whom reference should be made were I writing a full account of pyrexia; this is because I believed the founder's wish to be that lecturers should relate what they themselves had done and thought rather than that they should give a condensed account of what others bad done and thought.

\section{A SECOND SERIES OF FOURTEEN CASES OF EXCISION OF THE RECTUM.}

BY F. T. PAUL, F.R.C.S, ENG.,

SURGEON TO THE LIVERPOOL ROYAL INFIRMARY.

A PAPER on the first series of fourteen cases was read at a meeting of the Liverpool Medical Institution two years ago. ${ }^{1}$ They were all malignant; thirteen were carcinoma and one was sarcoma. The present series is comprised of two cases of syphilitic stricture, two of villous tumour, and ten of carcinoma.

The minute structure. - I make it a rule to examine with the microscope all tumours removed, and it is strange how frequently one finds deviations from the normal type of growth, or something altogether unexpected. The first example of this in this series was Case 17. The patient was a spare, anæmic woman, aged fifty-six years, who had five years' history of constant desire to defæcate, with passage of mucus and blood. On examining her a very large mass of what was supposed to be soft fungating carcinoma was felt two and a half inches from the anus. It surrounded the 
bowel and extended up out of reach. Six inches of rectum were removed by the "sacral route." She made a slow but good recovery, and is still well. I only discovered something unusual about this tumour when, on putting a piece into the fixing solution, villous fringes floated out in the fluid. Further investigation showed that the whole of this mass of growth, which involved more than three inches of the whole circumference of the bowel, and was upwards of an inch thick, consisted of branching villi covered with a single layer of long columnar cells having small nuclei placed near their bases. Villous tumours of the rectum are supposed to be rare, and I have never seen a report of one so extensive as this. The patient was operated on in July, 1895, and she was still quite sound in April, 1897. The other case of villous tumour was much smaller and was recognised as a probably innocent growth before operation. It occurred in Case 25 , in a woman also aged fifty-six years, and occupied an oval patch on the anterior wall of the rectum about 2 in. by 1 in., and was situated two inches above the anus. It was excised with the whole thickness of the bowel through a posterior median incision. The parts were sutured, and a normal rectum resulted. She has left ber old address, and I cannot find her; but in such a case recurrence is practically out of the question. The microscopical structure is like the last-essentially innocent.

The next two cases worthy of attention on account of their pathological interest are those of a man aged twenty-seven years, and a woman aged forty-six years (Cases 23 and 26). Both were admitted with malignant stricture, and both had a history of the previous removal of a polypus-the man in New York seven months previously, and the woman in London in St. Bartholomew's Hospital by Mr. Willett three years previously. The polypus in the man's case may have been malignant, for the tumour had the usual characteristics of colloid cancer; but that in the case of the woman was probably, nay, almost certainly, innocent, for the entire piece that I took was pure villous tumour, in which the other coats of the bowel, including the sub-mucous coat, were absolutely normal. Another part, however, examined by Mr. Robert Bickersteth, was cancerous. of course, we knew the tumour was in part malignant, for there were cancerous glands in the meso-rectum. No doubt the part I examined was some of the original disease-a simple villous tumour. But the original growth in time became malignant, and thus furnishes another example to those who doubt that innocent tumours may become malignant. Another point of interest in the man's case was that he had a malignant gland (of the same character) in the left groin. This is the only time that I have seen cancer in a gland in the groin secondary to a growth placed well within the rectum. During my absence last year another case of villous tumour becoming malignant was admitted. It consisted of three polypoid masses, one of which has the appearance of villous tumour, but the others of cylindrical-celled carcinoma. It was very successfully excised through a posterior median incision by $\mathrm{Mr}$. Robert Bickersteth. The man left with a normal rectum and has remained well since. Thus no less than four (possibly five) cases of villous tumour of the rectum have been met with in one year, though only two retained their innocent features at the time of examination. I can quite understand that those who have not the opportunity of seeing these specimens may feel a little sceptical at such an extraordinary percentage, but in about fifty cases of tumour of the rectum which I have examined microscopically these are the only examples of villous tumour met with.

In the first series of cases I called attention to one of squamous-celled epithelioma, which started in the mucous membrane of the bowel (Case 8). In this series there is another (Case 21). It occurred in a woman aged forty-seven years, and caused a tight stricture one-and-a-half inches above the anus. It infiltrated the vagina, but evidently did not originate there, as the vaginal mucous membrane was intact. Such abnormal forms of carcinoma probably grow in "rests" or in tracts of tissue such as give rise to rectal dermoids. Finally, in this connexion, the evidence is again in favour of colloid being decidedly more malignant than cylindrical-celled carcinoma. I mention this, as the contrary opinion seems to prevail.

The operation. - The methods used may be arranged as follows: (1) perineal incision, which suffices for the removal of about three inches of bowel-more in the female; (2) the same, combined with excision of the posterior wall of the vagina, which gives a great deal of room-the vagino-perineal operation; (3) posterior median proctotomy for the removal of small growths with subsequent suture; and (4) the sacral operation of Kraske. In none of these cases has the upper part of the rectum been removed by abdominal section.

Partial excision of the rectum through the perineum is $a$ very successful operation. It is generally in these cases, in which the growth is small and situated near the anus, that we may hope for a long immunity. Growths higher up are longer in attracting the patient's attention, and the glands of the meso-rectum are often involved before they are recognised and sent for operation. If the patient is able to bear the complete operation, it is always better to excise the entire circumference of the bowel in all cases in which the removal is too extensive to permit restoration of its calibre by suture. In those cases in which I have removed a growth from the posterior wall and left part of the anterior wall and anus, the discomfort from mucous discharge and prolapse has been considerable, and I have found it desirable to subsequently cut away all exposed mucous membrane. In fact, the subsequent discomfort from these slight operations has generally far ezceeded that of the removal of six or seven inches of bowel.

The vagino-perineal operation is a good one, but it is, of course, essential to restore the vagina and perineum. I once saw a patient upon whom this operation had been performed without restoration, and the result was deplorable, for the whole of the pelvic organs prolapsed from want of support. When the diseased parts have been excised the stump of the rectum is brought out at the posterior end of the wound attached to a glass tube; the remains of the elastic wall of the vagina are sutured in front, and deep silver sutures are passed between the two and a very long perineum procured. Generally the anatomical result is excellent, and as a corroborative detail it may be mentioned that two of my younger patients married after this operation, but, perhaps fortunately, did not become pregnant.

The posterior median proctotomy for the removal of small growths with subsequent restoration of the bowel is perhaps the most interesting operation. A long backward incision is made, carried up over the sacrum if the tumour is in the middle third, and the bone is cut across and turned as a flap to the left side. The rectum is then opened in the middle line, and the disease examined with the finger. If it is a short stricture the entire circumference is excised; if an oval patch then only the affected part. In either case restoration is best effected by sutures and not by Murphy's button. Having sewn up the wound made in the bowel for the removal of the growth the posterior lineal incision is closed, the sacral flap restored, and the anus forcibly dilated to paralyse the sphincter. In some cases the result of this operation is nearly perfect.

The sacral operation of Kraske is, of course, the most serious. The incision is made as in the last case, the coccyx, or coccyx and lower part of the sacrum, being cut across and turned to the left. It is important to retain these bones, as when their support is lost the bowel may prolapse badly unless the special truss recommended in my former paper is worn. Having exposed the bowel, if the growth is high up it may be cut across below, and the anus left intact; if not, dissect it entirely up from below. There is no value in the lower piece of bowel, only its removal makes a large wound. Next, with constant use of compression forceps and aneurysm needle before the knife or scissors, clear the bowel until the meso-rectum is cut away and the peritoneum freely opened; then draw down as much as is necessary to insert a glass tube above the growth, ligature it in, and cut off the latter. Enough bowel must be drawn down to allow the end to be brought out of the wound without tension. The sacral flap is then restored, the bowel connected to the skin with sutures, and the rest of the large wound in front packed with cyanide gauze.

I have tried various ingenious methods, including Murphy's button, to approximate the upper and lower ends after ex. tensive removal, and I am now persuaded that any such attempt is bad practice when the excision exceeds two, or at most three, inches of bowel. The healing is longer and more dangerous and the result little, if any, better. It would occupy too much space to go into the reasons, but I have tried approximation after extensive removal several times, and $I$ regard it as a failure. It is certainly more dangerous than the glass tube method I formerly recommended, and to which I have decided to return. On the other hand, the use of a sacral flap in place of cutting away 
the bones is a distinct improvement, and I believe at the the success of the operation, apart from the physical powers present time only one patient is wearing a truss, and that of the patient and the skill of the surgeon. The chief of is for the partial perineal operation. All the Kraske cases these are: 1. Early recognition of the disease.-This means describe themselves as having little or no loss of control that either it is low down or has rapidly formed a ring over their bowels. In fact, they are more inclined to stricture stricture. In the majority of cases the early symptoms are than a patulous anus with prolapse.

Results. - The anatomical results have been referred to in describing the operations. The best result is obtained when a small growth or short segment has been removed and the parts have been satisfactorily united by suture. The next best is after the complete removal of the lower end of the bowel, whether by the perineal, vagino-perineal, or sacral operations; it does not matter how much is removed so that a clean end is brought out and the natural support of bones or perineum is made good. The worst anatomical results follow when a lot of exposed mucous membrane is left with a long slit-like anus, or when the support of the perineum or sacrum and coccyx is wanting.

Clinically there are many circumstances which influence slight, and when the patient seeks advice the tumour is already large. 2. The nature of the growth.-In innocent tumours the result should of course be cure, though in operating through the anus this does not appear to be the case with villous tumour. A villous tumour is generally a sufficiently serious affection to call for posterior median proctotomy. Of malignant tumours the usual cylindricalcelled carcinoma of the part offers the best prospect; squamous-celled epithelioma perhaps the next best; colloid and sarcoma the worst. 3. Involvement of glands. Wherever I find malignant glands in the meso-rectum I always regard the case as certain to have a recurrence. Occasionally the glands may be recognised before operation,

Table of Twenty-eight Cases of Excision of the Rectum

\begin{tabular}{|c|c|c|c|c|c|c|c|c|c|c|}
\hline 熍 & 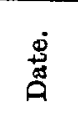 & $\begin{array}{l}\dot{x} \\
\dot{0} \\
\dot{n} \\
\dot{n}\end{array}$ & $\underset{8}{9}$ & Site of tumour. & Operation. & $\begin{array}{l}\text { Amount } \\
\text { removed. }\end{array}$ & Result. & Died Iater. & Still living. & Remarks.* \\
\hline 1 & 1881 & M. & 47 & $\begin{array}{l}\text { Lo } 0 \text { er third of } \\
\text { rectum, small. }\end{array}$ & $\begin{array}{l}\text { Through peri- } \\
\text { neum. }\end{array}$ & 2 in. & Recovered. & - & $\begin{array}{l}10 \text { or more } \\
\text { years. }\end{array}$ & $\begin{array}{l}\text { Shown at Liverpool Medical Insti- } \\
\text { tution, 1885. Left in good health } \\
\text { for America, 1891. }\end{array}$ \\
\hline 2 & 1888 & $\mathbf{F}$ & 55 & $\begin{array}{l}\text { Lower third, } \\
\text { small. }\end{array}$ & $\begin{array}{l}\text { Through peri- } \\
\text { neum. }\end{array}$ & $2 \frac{1}{2}$ in & Recovered. & $2 \frac{1}{2}$ years. & - & Had stricture of rectum. \\
\hline 3 & 1890 & F. & 37 & $\begin{array}{l}\text { Middle third; } \\
\text { sarcoma. }\end{array}$ & Kraske (tube). & $7 \mathrm{in.}$ & Recovered. & One year. & - & $\begin{array}{l}\text { Died of recurrence in internal } \\
\text { organs and skin at distant parts. }\end{array}$ \\
\hline 4 & 1890 & M. & 46 & $\begin{array}{l}\text { Middle and lower } \\
\text { thirds. }\end{array}$ & Kraske (tube). & $6 \frac{x}{2} \mathrm{in}$. & Recovered. & Ten months. & - & $\begin{array}{l}\text { Previous colotomy. A small piece } \\
\text { of growth left in ureter. }\end{array}$ \\
\hline 5 & 1891 & M. & 41 & $\begin{array}{c}\text { Middle and lower } \\
\text { third s. }\end{array}$ & Kraske (tube). & 7 in. & Recovered. & 4 years. & - & $\begin{array}{l}\text { No recurrence for three years. At } \\
\text { work all the time. }\end{array}$ \\
\hline 6 & 1891 & F. & 55 & $\begin{array}{c}\text { Middle and lower } \\
\text { thirds. }\end{array}$ & Kraske (tube). & 5 in. & Died. & - & - & $\begin{array}{c}\text { Died on the eleventh day. } \\
\text { Exhaustion. }\end{array}$ \\
\hline 7 & 1892 & M. & 56 & Middle third. & Kraske (tube). & 8 in. & Recovered. & $2 \frac{1}{2}$ years. & - & At work for two years as agent. \\
\hline 8 & 1892 & F. & 29 & Lower third. & $\begin{array}{l}\text { Vagino.perineal } \\
\text { incision. }\end{array}$ & 4 in. & Recovered. & 21 years. & - & $\begin{array}{l}\text { Removed part of vagina. Very well } \\
\text { for some time. Got married. }\end{array}$ \\
\hline 9 & 1893 & M. & 59 & $\begin{array}{l}\text { Lower third. } \\
\text { small. }\end{array}$ & $\begin{array}{l}\text { Through peri- } \\
\text { neum. }\end{array}$ & 3 in. & Recovered. & - & 4 years. & Working all the time. Very well. \\
\hline 10 & 1893 & M. & 64 & $\begin{array}{l}\text { Middle third, } \\
\text { small. }\end{array}$ & $\begin{array}{c}\text { Kraske } \\
\text { (approximation) }\end{array}$ & $2 \mathrm{in.}$ & Recovered & Lost sight of & alter 2 years. & Perfectly normal rectum. \\
\hline 11 & 1893 & F. & 42 & Lower third. & $\begin{array}{l}\text { Vagino-perineal } \\
\text { incision. }\end{array}$ & $4 \mathrm{in.}$ & Recovered. & 10 months. & - & $\begin{array}{l}\text { Rapid recurrence owing to infected } \\
\text { lymphatics. Part of vagina re- } \\
\text { moved. }\end{array}$ \\
\hline 12 & 1893 & M. & 56 & Lower third. & $\begin{array}{c}\text { Kraske } \\
\text { (approximation). }\end{array}$ & $4 \mathrm{in.}$ & Recovered. & 一 & $3 \frac{1}{2}$ years. & Normal rectum. \\
\hline 13 & 1893 & M. & 64 & $\begin{array}{c}\text { Middle and lower } \\
\text { thirds. }\end{array}$ & $\begin{array}{c}\text { Kraske } \\
\text { (approximation). }\end{array}$ & $4 \frac{1}{2}$ in. & Recovered. & $2 \frac{1}{3}$ years. & - & Anus incomplete behind. \\
\hline 14 & 1894 & M. & 60 & Middle third. & $\begin{array}{l}\text { Kraske } \\
\text { (tube). }\end{array}$ & $4 \mathrm{in.}$ & Died. & 一 & - & $\begin{array}{l}\text { Patient greatly reduced by pre- } \\
\text { vious complete obstruction and } \\
\text { colotomy. }\end{array}$ \\
\hline 15 & 1895 & M. & 60 & Lower third. & $\begin{array}{l}\text { Through peri- } \\
\text { neum. }\end{array}$ & 4 in. & Recovered. & 1 year. & - & Adherent to bladder. \\
\hline 16 & 1895 & M. & 64 & $\begin{array}{l}\text { Lower and middle } \\
\text { thirds. }\end{array}$ & $\begin{array}{c}\text { Kraske } \\
\text { (approximation) }\end{array}$ & $7 \frac{1}{2}$ in. & Recovered. & 6 months. & - & Had malignant glands. \\
\hline 17 & 1895 & $F$ & 56 & $\begin{array}{l}\text { Middle third } \\
\text { (villous). }\end{array}$ & $\begin{array}{l}\text { Kraske } \\
\text { (tube) }\end{array}$ & 6 in. & Recovered. & 一 & 20 months. & Good anus. \\
\hline 18 & 1895 & F. & 23 & $\begin{array}{l}\text { Lower and middle } \\
\text { thirds. }\end{array}$ & Kraske (tube). & $4 \frac{1}{2}$ in. & Recovered. & $?$ & - & $\begin{array}{l}\text { Very well for some time. Married. } \\
\text { Recurrence after one and a balf } \\
\text { years. Not seen lately. }\end{array}$ \\
\hline 19 & 1895 & F. & 34 & $\begin{array}{l}\text { Eatire rectum } \\
\text { (syphilitic). }\end{array}$ & Kraske (tube). & $5 \mathrm{in.}$ & Recovered. & - & 17 months. & Much better. \\
\hline 20 & 1896 & F. & 64 & Lower third. & $\begin{array}{l}\text { Through peri- } \\
\text { neum. }\end{array}$ & $3 \times 2$ in. & Recovered. & - & 13 months. & No recurrence. \\
\hline 21 & 1896 & F. & 47 & Lower third. & $\begin{array}{l}\text { Vagino- } \\
\text { perineal. }\end{array}$ & 3 in. & Recovered. & - & 12 months. & No recurrence; good anus. \\
\hline 22 & 1896 & F. & 25 & $\begin{array}{l}\text { Lower third } \\
\text { (sy } \rho \text { hilitic). }\end{array}$ & $\begin{array}{l}\text { Through dilated } \\
\text { rectum. }\end{array}$ & $\frac{1}{2}$ in. & Recovered & - & 11 months. & $\begin{array}{l}\text { Diaphragm stricture; perfect } \\
\text { restoration. }\end{array}$ \\
\hline 23 & 1896 & M. & 27 & $\begin{array}{c}\text { Middle and lower } \\
\text { thirds. }\end{array}$ & Kraske (tube). & 4 in. & Recovered. & - & 10 months. & Glands infected. \\
\hline 24 & 1896 & F. & 57 & $\begin{array}{l}\text { Middle and lower } \\
\text { thirds. }\end{array}$ & Vagino-perineal. & $4 \frac{1}{2}$ in. & Recovered. & - & 10 months. & Colloid growth; glands. \\
\hline 25 & 1896 & F. & 56 & $\begin{array}{l}\text { Middle third } \\
\text { (villous). }\end{array}$ & $\begin{array}{l}\text { Post. median } \\
\text { proctotomy. }\end{array}$ & $2 \times 1 \frac{1}{3}$ in & Recovered. & - & 8 months. & Normal rectum. \\
\hline 26 & 1896 & F. & 46 & $\begin{array}{c}\text { Middle and lower } \\
\text { thirds. }\end{array}$ & $\begin{array}{c}\text { Kraske } \\
\text { (approximation) }\end{array}$ & 4 in. & Recovered. & - & 6 months. & Cancer following villous tumour. \\
\hline 27 & 1893 & M. & 63 & $\begin{array}{l}\text { Middle third, } \\
\text { extensive. }\end{array}$ & $\underset{\text { (approximation) }}{\text { Kraske }}$ & $3 \frac{1}{2}$ in. & Died. & - & - & calised peritonitis; shock. \\
\hline 28 & 1896 & $F$ & 34 & Lower third. & Vagino perineal. & $3 \frac{1}{2}$ in. & Died. & - & $\longrightarrow$ & $\begin{array}{l}\text { Cancer very foul. Exhausted } \\
\text { patient. Shock and septio wound. }\end{array}$ \\
\hline
\end{tabular}

\footnotetext{
* The tumours were malignant where not other wise mentioned.
} 
The younger the patient the less the chance of permanent cure. I have now seen quite a dozen cases under twenty-five years. The rectum is, I think, the earliest of all sites for true carcinoma, though a majority of the patients are between fifty and seventy years of age.

In regard to the survival of my cases after the operation I wan speak with some degree of certainty, as I have taken considerable pains to keep them under observation. of the first series of fourteen all were cases of malignant disease. One was certainly cured; several survived for from one to four years, and I predicted that one if not two more would prove to be cured. I am glad to report that wo far this prediction seems likely to be fulfilled. One is a patient of Dr. Peirce, of Hoylake, and I hear that the is sound and well, working every day on his farm at the age of sixty-three years. The other is a patient of Dr. Gwynn, of Whitchurch, and he writes me that this man is "so well that he has not seen him for months," and having now re examined him reports that "there is no appearance of a return of the disease, and the control over the parts is good." In the former the operation was done rather more, and in the latter rather less, than four years ago. Of the first fourteen cases of malignant disease, the last of which was operated on more than three years ago, I can now make the following definite report. Two died from the operation; three are cured; one was under observation for ten years and the other two for four years. One more I am almost certain is cured, but I lost sight of him after two years, when he was perfectly well. He lives in the heart of Wales, and all my letters come back without having reached him. The remaining eight averaged just two years of life after the operation, all of them dying from recurrence. In my judgment there are very few parts of the body where better results can be obtained when dealing with cancers of considerable dimensions.

In regard to the second series of fourteen cases four are non-malignant. They are all well and likely to remain so. Of the ten cancer cases two died from the operation, and two more have died since from recurrence, one at the end of twelve months and the other at the end of six months. This has been rather an unlucky series of cases, many of them having had enlarged glands in the meso-rectum at the time of the operation. I dare only predict that one may prove a cure-Case 20, a woman aged sixty-four years, who had a cylindricalcelled carcinoma $2 \frac{1}{2}$ in. by $1 \frac{1}{2}$ in. on the posterior wall of the rectum about two inches from the anus. In Case 21 I examined the patient in May, and she is quite free from recurrence twelve months after operation; but her tumour proved to be squamous-celled carcinoma, and I bave less hope of cure in this form of growth. However, things may turn out better than I expect. Six of the ten operated on during the last two years are well and, so far as I can tell, without fresh growth. The case in which $\mathrm{Mr}$. Robert Bickersteth operated for me, which is not included in the table, has probably a better prospect of permanent cure than any of the others.

Fatal cases.-The mortality is exactly the same for both series-namely, 14 per cent. In the first series the two death occurred in elderly patients and were the result of shock, one dying gradually on the eleventh day from exhaustion and the other rapidly soon after the operation. In the present series I had no death until the last two cases-the îrst in an old man, aged sixty-three years, who died on the sixteenth day from chronic septic poisoning, and in whom localised peritonitis was found. I blame the result here upon approximating the bowel after an extensive removal. The union was imperfect and the wound became septic before the peritoneum had healed. Had I brought the stump ont and connected it with the glass tube the operation would have been shortened by perhaps half an hour and the wound would not have been contaminated with fæces until the peritoneum had closed. The second death occurred in a young woman with a remarkably foul cancer. It was so virulent that every little crack in the skin of my hands became poisoned, and I had five sores which refused to heal till I left home. No wonder that her wound was septic and that she, being in a very anæmic and exhausted condition at the time of the operation, gradually died on the twenty-fifth day. The peritoneum was not opened in her case.

Although the cancer cases are, on the whole, less favour able in this series than the last, I continue to thoroughly appreciate the value of the operation of excision of the rectum. In the less severe cases one has an excellent chance of obtaining a cure, and in many of the bad ones there is a considerable period of immunity during which life is by no means a burden to the majority.

The syphilitic cases.-Having included two cases in which I operated for syphilitic stricture, it is right that I should say a word respecting them. Case 22 offered such a tempting opportunity for a "radical" cure that I at once suggested that we should excise the stricture without attempting dilatation with bougies. She had a diaphragmatic stricture about an inch above the anus, and after dilating the latter I was able to draw it outside and excise it without the least difficulty. The wound was carefully sutured, it healed by first intention, and when examining her a month or two subsequently I could not detect the site of the operation. Case 19 was a very different business. Here we had an anæmic patient who had suffered for years from incurable syphilitic stricture. I had done what I could with bistoury and bougies, and it was her own desire that stronger measures should be taken. Under these circumstances, as life was really a burden to her I made the Kraske's incision and attempted to excise the whole rectum. Bat it was a more difficult and dangerous operation than I anticipated, owing to the dense adhesions contracted by the bowel with all neighbouring structures, and I found when I had got five inches freed that her condition was such as to make it imperative to conclude the operation at once. A glass tube was consequently ligatured in, the wound was packed with gauze, and the patient was sent back to the ward. Convalescence was slow, but in the end she recovered. There are still some two or three inches of strictured bowel, but it is not so narrow as that which was removed and yields to bougie treatiment, which she is now carrying out herself. I have no reason to suppose that this patient is dissatisfied with the result of her operation, and she is certainly much better pleased in having the artificial anus near the old spot than she would be if it were in the groin, but knowing now myself the difficulties and dangers to be encountered in bad cases of syphilitic stricture $I$ should in future have no hesitation in recommending colotomy when it was impossible to obtain relief by simpler measures. This, of course, does not apply to special cases like Case 22. Here no danger whatever is run, and there is no reason to object to excision if the surgeon thinks it to be the best method of relieving his patient.

Liverpool.

\section{THE LOCALISING VALUE OF OPTIC NEURITIS IN INTRACRANIAL TUMOUR.}

BY J. M. MARTIN, B.A, M.B., B.C. CANTAB.

DURING the last thirty years general opinion has wavered greatly as regards the certainty and frequency with which optic neuritis is produced by a growth within the cranium, and the greatest authorities from time to time have made diametrically opposite statements with regard to this con. dition. At various times it has been stated that optic neuritis has no localising value as regards the seat of disease, and at other times the directly contrary opinion has been put forward. Thus Dr. Hughlings Jackson in 1880 stated that " optic neuritis is of no value in localising di sease in any part of the cerebrum or cerebellum," and Mr. Horsley now holds that optic neuritis is of distinct value in locating the position of the disease, more particularly as regards the side on which the disease is situated. But it is when we come to the question of unilateral optic neuritis that we find the greatest difference of opinion. For some observers state that in a case in which optic neuritis appears only in one eye, or appears in one eye before the other, or is more marked in one eye than in the other, the seat of lesion is on the opposite side of the brain; whereas others equally positively state that the lesion is on the same side as the eye in which the optic neuritis first appears or is more marked. It is as an attempt to try to arrive at the true facts of the case by examining rather a larger number of reports than has been presented before that I now kring forward the results of my analysis of 600 cases, which I have collected from various sources. Before I begin the diacussion cf the special subject B 2 